\title{
Homo faber or homo credente? What defines humans, and what could Homo naledi contribute to this debate?
}

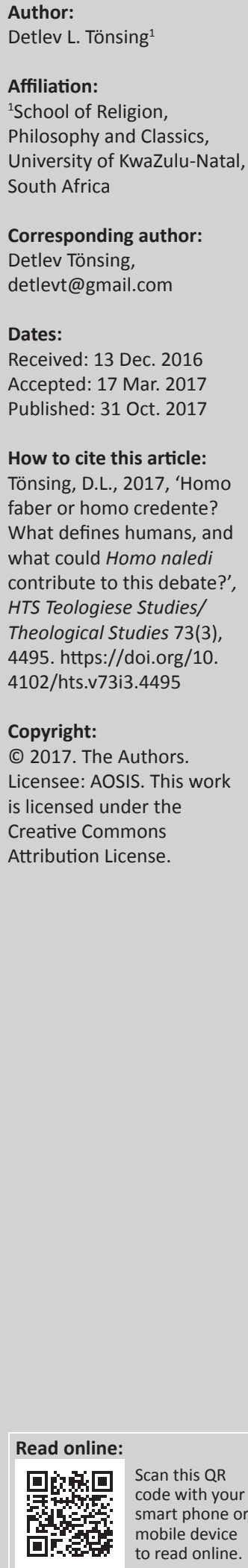

The transition from pre-human to human has, for a long time, been associated with tool use and construction. The implicit self-definition of humans in this is that of planned control over life world. This is reflected on in the work of Hanna Arendt on the homo faber and the novel by Max Frisch of that name. However, this definition has become problematic in a number of ways: Planned tool use has been seen to occur outside the human species, and the focus on control of the environment has become suspect because of the environmental crisis. The burial practices of Homo naledi indicate high-level self-awareness and social communication, with little tool use being evident. This article asks whether this might be an occasion to redefine our conception of what it means to be human away from the focus on mastery and control and towards including trust, also religious trust, as the true mark of humanity.

\section{What is human?}

What is the human being? This question, on which humans have reflected from early times (e.g. Ps 8:1), is still of relevance, also in the study of human evolution. There is some debate on whether the use of the genus Homo in the description of the finds in the Dinaledi cave is appropriate. What qualifies the use of Homo in Homo naledi?

In the history of human evolution studies, the transition to the species Homo was generally linked to complex, planned tool construction as an indication of human-like behaviour (Dunbar 2014; Leakey 2009; Plummer 2004). This is evidenced in such names as Homo ergaster or Homo habilis. The transition from the age of the australopithecines to the genus Homo is held to concur with the time at which stone tools also begin appearing in the archaeological record, about 2.6 million years ago (Roger [1984] 2005). Thus, in this period of the study of evolution, the implied selfdefinition of human is ultimately technological: The defining characteristic of being human is the incipient control of the world through tools.

Tools are instruments with purpose. They contribute to improved survival of humans. But the instrument cannot determine the final, nor can the tool determine the purpose of its use.

\section{Homo naledi}

The primary association of tool-making and self-definition of humans has been questioned recently - with arguments that the transition to the larger, more costly brain size associated with the genus Homo should be associated more primarily with the use of fire or the use of language as instrument of social bonding (Dunbar 2014).

In this context, the discovery of the fossils in the Dinaledi cave may contribute to the discussion (Berger et al. 2015). Especially interesting is the configuration of the fossils discovered. The important aspects of the configuration are the following:

- Many hominin bones are found clustered together.

- A significant number of these are fairly intact, the bones of, for instance, a hand, a foot and a cranium retaining a large degree of articulation.

- The fossils are found in a fine clay matrix, without larger breccia components.

- There are only a small number of bird and rodent fossils found in the site.

- There are no signs of predations (tooth marks on the bones or similar).

- There are no signs of vertical access to the cave directly above the Dinaledi Chamber where the fossils were found (Dirks et al. 2015).

This strongly suggests that the bodies of deceased members of $H$. naledi society were carried to this cave, which is very difficult to access, by other hominins, purposefully over an extended 
period of time (Randolph-Quinney 2015). That the bones were gathered because of predation is excluded by the absence of bite and chew marks or other animal fossils of comparable size. Accidental falling into through a vertical access is excluded by the absence of other bones, or of breccia, or signs that this chamber was, at any stage, vertically accessible. Water or mud carrying the bones in is again excluded by the absence of breccia and other bones, and the high degree of retained reticulation (Dirks et al. 2015). We therefore, provisionally, and knowing that this is still a matter of controversy in the scientific community (e.g. Val 2016), proceed under the assumption that $H$. naledi likely engaged in the practise of carrying dead members of the society on a difficult route to this part of the cave (Dirks et al. 2016).

This is interesting because it shows the following:

- a high degree of social, co-operative behaviour

- planned, purposeful actions

- planned, purposeful actions that did not have immediate contribution to their survival as the purpose.

It is, of course, impossible to divine the thoughts and motivations of the members of this $H$. naledi group as they carried in deep darkness the dead bodies of their kin on the difficult and treacherous route to one of the deepest and most inaccessible caves available in the area. However, we may speculate that this is evidence of a burial practice that had religious connotations - maybe a return to the bowels of the earth as the womb from which life originates.

What is clear is that human-like planned, purposeful behaviour was already present in this very early member of the hominin family, not only directed at mastery of nature and survival but also linked to something different from pure practicality. It seems that strong social bonds were important, but perhaps also the recognition of humans as emanating from, and returning to, a mystery.

Of course, we need to guard ourselves against the naturalistic fallacy: even if certain behaviours were definitely part of our origin as humans, it does not mean that we ought to pursue these behaviours - as, for instance, the evidence for cannibalism among Neanderthals illustrates.

However, reflection about what made $H$. naledi human may help us, as through a mirror, to reflect on what we think and believe to be important for our humanity. It is to this consideration that we turn now to using literature as a mirror to reflect on this question.

\section{Homo faber}

The phrase homo faber was coined by Appius Claudius Caecus, who formulated its meaning in the sentence 'Homo faber suae quisque fortunae' (Every human is the maker of his or her destiny) (World Heritage Encyclopedia s.d.). Homo faber thus stands for human as the makers, the makers of instruments and the makers of their own life.
Hannah Arendt (1958) differentiates three aspects of being human:

- In as far as we labour to meet the basic needs of survival, like all animals, we are animal laborans - and so slave to the needs of the body and still unfree. To be free, we need to move beyond slave labour to creative work.

- Beyond labour, by making instruments that persist, we create a human-designed world that separates us from the purely animal, and so are homo faber, who creates a truly human life world for themselves.

- However, because the homo faber creates instruments, the purpose of these instruments is not yet defined. For Arendt, the purpose of the action of humans, in order to be truly human, must be the freedom to act as a human, and therefore humanity comes to itself only as a zoon politikon, acting in the public realm out of and for freedom.

Therefore, for her, the true humanity of humans is in their social being, in their co-operation with each other. The social behaviour of humans seems to go back far into our roots - if $H$. naledi indeed can be seen to have engaged in burial-type behaviour.

Max Frisch wrote a novel with the name Homo faber: Ein Bericht (Frisch [1969] 1957). The main character, Walter Faber, starts out as a hardnosed Swiss engineer, believing in nothing but science, causality and chance, and dismissing the concept of 'an experience'. He sees computers as the true pinnacle of rationality, because these are without emotions or experiences, simply calculating data in a causal, reproducible manner. Through a number of improbable coincidences and decisions that seem to make little sense, he meets up with the brother of a friend from student days. Travelling to the plantation in South America to meet this friend, he finds that this friend has committed suicide. On the journey, he meets a young woman with whom he begins a relationship. He then finds out that she is his daughter, of whose existence he had been unaware. She is bitten by a snake, and though he takes her to hospital, she dies of skull fracture complications because of a fall. In the end, he realises the beauty he has missed in life - though the novel ends inconclusively. The novel has, among its many facets, the implication that simple manipulative and dominating, toollike rationality is insufficient for true humanity.

Homo faber stands, in this article, for the human being who controls his life through mastery of the world. Both Arendt and Frisch suggest that humans must be more than just homo faber - because instrumental domination cannot, in the long run, be a purpose - it must serve something more.

Whether this something more can be freedom or whether freedom, as freedom to act, is but of instrumental value is a dialogue with Arendt which is not to be pursued at this point.

However, it is clear from the current state of the world that instrumental domination as the primary human selfdefinition is detrimental to the integrity both of human society and of the ecology of our planet: Because of the very effective 
quest of humans to ensure their domination through the instrument of technology, the balance of the many ecosystems of the world is threatened, and the extinction of species is proceeding at an unprecedented rate. Also, the detrimental effects of climate change are threatening long-term negative consequences to world-wide ecological balance. This is public knowledge.

Similarly, the human quest for instrumental domination is detrimental to societies because the accumulation of power, most easily measured in terms of wealth, as a primary goal of life results in wealth and power imbalances that undermine both human dignity and the stability of social systems. The increasing wealth gap and the consequent poverty levels are publicly recognised to be a threat to social stability. Thus, homo faber as human self-concept is problematic.

What I want to draw from these reflections out of literature and philosophy is that instrumental reason, technical reason, reason that helps us survive through dominating our environment, is not enough, and indeed is dangerous, for our humanity - we need more.

It is maybe an inkling of this 'more' than surviving the predators that motivated $H$. naledi to brave the deep, dark cave to deposit the remains of their kin there.

\section{Homo credente}

To approach this 'more' somewhat further, I turn to another philosopher, Martin Heidegger.

In a speech, published under the title Gelassenheit, Heidegger ([1966] 1959) describes the dominant rationality of our time as calculating thinking (rechnendes Denken) that computes likely consequences and determines likely paths to intended goals - it is ultimately instrumental. This is of course necessary for everyday life.

Yet, it is to be contrasted with, and supplemented by, meditative thinking (besinnliches Denken), which waits and allows the depth of reality to intimate itself to us - which leaves itself behind to attempt to understand something that is not subject to our calculating use, but beyond ourselves - a mystery.

The danger, if the calculating thinking dominates, is that the relationship of humans to the world changes: The world becomes seen as nothing more than a resource for human exploitation, and the human loses himself in subjection to the ever-increasing speed of technological advance. To again find himself, his own rootedness and autochthony again, humans need Gelassenheit (releasement, composure) toward things and openness toward mystery. For the openness to mystery in meditative thinking is constitutive for the essence of human beings.

This reminds of Klaus Nürnbergers book, Regaining Sanity for the Earth: Why Science Needs Best Faith to Be Responsible, Why Faith Needs Best Science to Be Credible (2011). The technical, calculating, instrumental thinking of our time needs to be supplemented, and indeed contained, by an awareness of values deeper than utility for survival, of something greater than we are - of a mystery.

It is this openness to something more than that which is necessary for survival that I mean when I coin the term homo credente - the person of faith, the human being which finds itself in relation to something greater, from which it derives itself and to which it returns. It is this more that enables us to experience the world not only in terms of utility but to have experiences of beauty, of wonder, when we see moonlight on the sea or the opening of a flower, or a bird singing. It is this more than utility and domination that informs the novel of Frisch and the philosophy of Arendt and Heidegger.

In the discourse of science and religion, the attempts to include the mystery of the 'more', the transcendent, into the ambit of a scientific understanding of the world have not led to any definite answers. I suggest that this is necessarily so: The sciences, which proceed on the basis of measurability and repeatability, fundamentally are associated with calculating thinking, with reason in as far as it relates to instrumental domination of the world. The close co-operation of science and technology is indeed part of their very nature. But humans do not, and cannot, live only in order to acquire the instruments that ensure their survival and domination of their world. To the contrary, humans need purpose so that what they do in their life, including the use that they make of the world, may have meaning. It is in relation to something more than mere survival that humans can make meaningful sense of their world. It is the self-definition in this relation for humans are fundamentally social beings of relationship to the transcendent, to the mystery out of which, and to which one lives that I denote by speaking of homo credente.

It is, I can imagine, this intimation of mystery which drove $H$. naledi to carefully and with great difficulty carry their kin the difficult passage to the deep, dark cave in the bowels of the earth. Acknowledging a mystery out of which we come, to which we are in relation, and which is both our ultimate source and destiny, should lead us to think about the world differently and to relate to it differently. If the mystery is greater, then not our mastery over the world but our trust in and accountability to that which is greater should form our underlying attitude. I believe we need to recover this awareness of mystery so that the ever-advancing, everquicker development of technology does not rule over us, and causes us to destroy an earth which we see as but a resource for our needs, but can be used by us without skewing our humanity, and can be constrained by us to not destroy the earth, on which we are dependent for our survival. If the surprising configuration of bones in the Dinaledi cave, and the discovery of the hominin $H$. naledi, would lead us to at least question our self-definition as Homo sapiens, in the direct descent from $H$. ergaster, and therefore our reason as instrumental domination, then indeed this discovery might be more than just interesting. It could be salutary. 


\section{Acknowledgements}

\section{Competing interests}

The author declares that he has no financial or personal relationships which may have inappropriately influenced him in writing this article.

\section{References}

Arendt, H., 1958, The human condition, University of Chicago Press, Chicago, IL.

Berger, L.R., John, H, de Ruiter, D.J., Churchill, S.E., Schmid, P., Delezene, L.K. et al., 2015, 'Homo naledi, a new species of the genus Homo from the Dinaledi Chamber, South Africa', elife Sciences Publications 4, 1-35. https://doi.org/10.7554/ eLife.09560

Dirks, P.H.G.M., Berger, L.R., Hawks, J., Randolph-Quinney, P.S., Backwell, L.R. \& Roberts, E.M., 2016, 'Deliberate body disposal by hominins in the Dinaled Chamber, Cradle of Humankind, South Africa?', Journal of Human Evolution, 1-5. https://doi.org/10.1016/j.jhevol.2016.04.007

Dirks, P.H., Berger, L.R., Roberts, E.M., Kramers, J.D., Hawks, J., Randolph-Quinney, P.S et al., 2015, 'Geological and taphonomic context for the new hominin species Homo naledifrom the Dinaledi Chamber, South Africa', eLife Sciences Publications, 4, 1-37, https://doi.org/10.7554/eLife.09561
Dunbar, R., 2014, Human evolution: A Pelican introduction, Penguin, London. Frisch, M., 1957 [1969], Homo Faber: Ein Bericht, Rowohlt, Reinbek bei Hamburg. Heidegger, M., 1959 [1966], Gelassenheit, Günther Neske, Pfullingen, transl. J.E. Anderson \& H.E. Freund, Discourse on thinking, Harper \& Row, New York.

Leakey, R.E., 2009, 'Early humans: Of whom do we speak?', in E.G. Frederick, G.F. John \& E.L.

Richard (eds.), The first humans: Origin and early evolution of the genus Homo, pp. 1-6, Springer, Berlin.

Nürnberger, K., 2011, Regaining sanity for the earth: Why science needs best faith to be responsible; Why faith needs best science to be credible, Cluster Publications, Pietermaritzburg.

Plummer, T., 2004, 'Flaked stones and old bones: Biological and cultural evolution at the dawn of technology', Yearbook of Physical Anthropology 47, 118-164. https:// doi.org/10.1002/ajpa.20157

Randolph-Quinney, P.S. 2015. 'A new star rising: Biology and mortuary behaviour of Homo naledi', South African Journal of Science 111, 9-10. https://doi.org/10. 17159/SAJS.2015/A0122

Roger, L., 2005 [1984], Human evolution: An illustrated introduction, Blackwell, Oxford.

Val, A., 2016, 'Deliberate body disposal by hominins in the Dinaledi Chamber, Cradle of Humankind, South Africa?', Journal of Human Evoluation 96, 145-148. https:// doi.org/10.1016/j.jhevol.2016.02.004

World Heritage Encyclopedia, s.d., Homo Faber, viewed 09 November 2016, from http://www.gutenberg.us/articles/homo_faber 